\title{
Polling and the New Hampshire Primary What to Watch, and Watch Out For
}

\section{David W. Moore and Andrew E. Smith}

$\mathrm{T}$ The New Hampshire primary is scheduled to take place on Tuesday, February 11, and numerous polls have told us and are telling us what the voters are contemplating "if the election were held today." In interpreting what the polls mean for the actual primary election, however, we need to take into consideration several caveats.

\section{Voters are mostly undecided, even close to election day.}

The polls typically ask respondents how they would vote if the election were held immediately, and most poll respondents will give some name. But that response doesn't mean they are committed: typically, leading up to the election anywhere between half and three quarters of voters are still trying to decide whom to choose. Thus, last-minute swings in support are possible and quite common.

For example, two months before the 2012 primary, 59 percent of Republican voters were unsure whom to vote for; the Sunday before 29 percent were still unsure. Two months before the 2016 primary, 55 percent of Republicans and 45 percent of Democrats were undecided, and in the mid-October $2019 \mathrm{CNN} /$ University of New Hampshire (UNH) poll 57 percent of Democrats were undecided. (Likely because there is not, as yet, a competitive Republican primary, only 28 percent of likely Republican primary voters were undecided, and the great majority said they would vote for President Trump.)

\section{Even "decided" primary voters can change their minds at the last minute-because there are no party differences among candidates.}

In a general election contest, voters' preferences are highly influenced by their party affiliation. Even voters who know little about the candidates can still rely on the candidate's party as an indicator of whom to choose. But in a primary contest, there is no party difference to anchor voter preferences, and if policy differences are slight the voter might vote for one candidate just as easily as another. Thus, last-minute ads, news stories, and campaign activities that suddenly favor one candidate over another can cause a major swing in voter preferences in a short time. Hillary Clinton trailed Barack Obama by an average of 8 percentage points in polls finishing Sunday before the 2008 primary, but a good debate performance on Saturday night and continuing news coverage of a "humanizing" incident at a Portsmouth coffee shop helped her sway last-minute voters and pull out a surprising 2 percentage point win.

\section{Pollsters' predictions of voter turnout are fraught} with problems that can distort results.

Unlike most states, New Hampshire allows any resident of voting age to participate in the primary, even if they are not previously registered, ${ }^{1}$ and anywhere from 10 to 15 percent of a New Hampshire primary electorate consists of people who register to vote at the polls on Election Day. Many pollsters use past primary voting lists as their source for sampling potential respondents, but that approach would exclude the "walk-in" voters, who could be demographically and politically quite different from the rest of the voters-thus resulting in misleading poll results.

\section{Final pre-election polls in the New Hampshire primary have often been right-but have just as often been wrong.}

Because of the factors mentioned above, the accuracy of polling in the New Hampshire primary has been inconsistent. In 2008, the polls did an excellent job predicting the Republican winner (John McCain), but they were all wrong predicting the Democratic winner (Hillary Clinton). Indeed, in every primary election from 1968 through 2000, the polling in New Hampshire differed significantly from the final results.

The major problem is that the polls typically stop two to three days before the election and therefore don't catch changes that occur right before people vote. Exit polls (taken as voters leave the voting booths) 
have consistently shown that one-third or more of New Hampshire voters made up their minds in the last three days before the election, and one in six made up their minds on Election Day itself.

Given these caveats, it's prudent to take a skeptical look at what the polls are showing us. They measure voters' top-of-mind reactions to the candidates, but with no guarantee that the voters will retain those views as the election approaches.

\section{The impact of only one competitive primary.}

Voters in New Hampshire can register as Democrats, Republicans, or undeclared. The 42 percent of registered voters in this last group are, unfortunately, often referred to by media and New Hampshire politicos as "independents." Most of them are not.

In fact, when the undeclared are asked if they lean toward either of the two major parties, most admit they do, with only about 10 percent of the electorate saying they do not lean to either party. Research shows that those who lean toward a party tend to vote the same way as those who are registered with that party. The undeclared voters who do not lean to a party are the least likely to vote.

With President Trump not facing a serious challenger so far in 2020, many in the media have wondered how the "independents" (or undeclared voters) might impact the Democratic primary. According to state laws, on primary election day undeclared voters can choose to vote in either the Republican or Democratic primary. (Voters registered as either Republicans or Democrats can choose to vote only in their party's primary.) Might many undeclared voters, even those who lean Republican, choose to participate in the Democratic primary? If so, how much of an impact could these socalled independents have on the outcome?

The short answer is: probably not much. Over time, most undeclared voters tend to vote only in one party's primary or another; very few choose to vote in a Republican primary one time and in a Democratic primary the next. Even though there is little competition in the GOP primary this time around, the vast majority of undeclared voters who lean Republican will either vote in their party's primary or not vote at all. And most of the undeclared voters who do not lean to either party will not vote.

Still, research shows that a small number of primary voters-about 3 percent-do switch parties from one election to another, depending on which primary seems to be more competitive. In very close contests, as the one in 2020 appears to be (as of this writing), it is possible that the results in the Democratic primary could be affected by undeclared voters, some of whom might be Republicans. So far, in New Hampshire's history, the undeclared voters have not determined the outcome in a primary, but pollsters need to be aware that the past is no guarantee of the future. They need to measure what undeclared voters intend to do.

\section{The lowa effect.}

One thing to keep in mind is that the Iowa caucuses just eight days before the New Hampshire primary can upend candidate standings in New Hampshire and render irrelevant any polls taken prior to the Iowa contest. But unfortunately for pundits, the "Iowa effect" is not always predictable.

For Republicans, recent history suggests the Iowa results have little effect on a candidate's standing in New Hampshire. Such was the case for George W. Bush in 2000, who won Iowa but lost big to John McCain in New Hampshire. Similarly, neither Mike Huckabee (2008), Rick Santorum (2012), nor Ted Cruz (2016) saw any boost in their New Hampshire standings after winning in Iowa.

However, not-so-recent history provides a different lesson. In 1980, for example, George H.W. Bush was initially helped in New Hampshire by winning in Iowa, as was Bob Dole in 1988. In 1996, Pat Buchanan was helped by his second-place showing in Iowa.

One explanation for the lack of an Iowa effect on New Hampshire for Republican candidates in recent times is that the electorates in the two states are different. Exit polls in 2008, 2012, and 2016, for example, showed that about 12 percent to 17 percent of Iowa caucus voters considered themselves "moderate" or "liberal," compared with 45 percent and 47 percent of New Hampshire primary voters in 2008 and 2012 but just 29 percent in 2016. More importantly, the percentage of evangelical Republicans voting in Iowa is almost three times greater than in New Hampshire: 57 percent versus 22 percent in 2012, and 64 percent versus 22 percent in 2016.

While history gives us a mixed message about the effect of Iowa on New Hampshire for Republicans, a good showing in Iowa for Democrats typically helps the candidate in New Hampshire. That was the case for Obama in 2008, John Kerry in 2004, Richard Gephardt and Paul Simon in 1988, Gary Hart in 1984, 
and Jimmy Carter in 1980 and 1976. The good showings in Iowa did not always translate into victories in New Hampshire (for example, Obama, Gephardt, and Simon), but they did give the candidates a boost.

In contrast with Republicans, the ideological profiles of Democratic voters in Iowa and New Hampshire are similar: In 2016, the last competitive cycle, exit polls showed Iowa with liberals outnumbering moderates/conservatives by 78 percent to 22 percent; in New Hampshire the comparable figures were 68 percent to 32 percent.

Given these data, one could speculate that, for Democrats, a victory in Iowa would give the winner a boost in New Hampshire. Still, even that pattern may be upset this year because of the large amounts of money available to candidates and because of the unusually large number of candidates. The screening process could be much slower this year, with wellfunded candidates able to continue their campaigns even if they lose in several of the early contests.

As for current polls predicting the winners in New Hampshire, history suggests considerable caution. As Yogi Berra might remind us if he were a cable news commentator, "It ain't over till it's over."

The Carsey Perspectives series gives authors the opportunity to present their analysis of important topics that is not based on original data analysis.

\begin{abstract}
About the Authors
David Moore is the founding director of the UNH Survey Center and a Carsey fellow. Andrew Smith directs the Survey Center at the University of New Hampshire and is a professor of practice in political science at the University of New Hampshire. They are coauthors of the book, The First Primary: New Hampshire's Outsize Role in Presidential Nominations.
\end{abstract}




\section{University of New Hampshire (1.) Carsey School of Public Policy}

The Carsey School of Public Policy at the University of New Hampshire is a nationally acclaimed resource for research, leadership development, and engaged scholarship relevant to public policy. We address the most pressing challenges of the twenty-first century, striving for innovative, responsive, and equitable solutions at all levels of government and in the for-profit and nonprofit sectors.

Huddleston Hall • 73 Main Street• Durham, NH 03824

(603) 862-2821

TTY UsERS: DIAL 7-1-1 OR 1-800-735-2964 (RELAY N.H.)

carsey.unh.edu 